\title{
Bulbuls and crows provide complementary seed dispersal for China's endangered trees
}

\author{
Bing Bai ${ }^{1+} \mathbb{B}$, Ning $\mathrm{Li}^{2 \dagger}$, Xinhai $\mathrm{Li}^{3}$ and Changhu $\mathrm{Lu}^{4^{*}}$
}

\begin{abstract}
Background: Different functional frugivores generally exhibit unequal contributions, both in terms of quantity (seed removal) and quality (seedling recruitment), to effective seed dispersal of plant species. However, variations in this dispersal pattern generated by frugivores across different regions are still unknown.
\end{abstract}

Methods: In our study, we evaluated the contributions of two functional frugivore bird groups, the bulbuls (Pycnonotidae) and crows (Corvidae), in both the seed removal and seedling recruitment of the endangered Chinese yew tree (Taxus chinensis) across three different geographical regions in eastern China.

Results: The dominant crow species, Urocissa erythrorhyncha, was the most common disperser crow species at all sites, while the dominant bulbul species varied across the three sites. Furthermore, the two functional groups of dispersers diverged in the aspects of seed removal (quantity) and seedling recruitment pattern (quality). While bulbuls outperformed crows in seed removal (quantity), crows took more seeds to a safer site for seedlings (quality).

Conclusions: Our results highlight the importance of variations in the effective seed dispersal patterns of different functional disperser groups across different regions in the conservation and management of endangered tree species.

Keywords: Complementary seed dispersal, Effective seed dispersal, Seed removal, Seedling recruitment, Taxus chinensis

\section{Background}

In tropical and temperate forests, more than $75 \%$ of woody species depend on frugivores for primary or secondary seed dispersal (Howe and Smallwood 1982). Seed dispersal is important for determining the composition, diversity, and structure of plant communities (Nathan and Muller-Landau 2000; Levine and Murrell 2003), which has important implications for the conservation and management of endangered plants (Trakhtenbrot et al. 2005).

For the conservation of endangered fleshy-fruited plants, it is important to explore how the plants form an effective dispersal pattern across different regions, which

\footnotetext{
${ }^{*}$ Correspondence: luchanghu@nifu.com.cn

${ }^{\dagger}$ Bing Bai and Ning Li contributed equally to this work

${ }^{4}$ Laboratory of Plant-Animal Interactions, College of Forest Resources and Environment, Nanjing Forestry University, Nanjing 210037, China Full list of author information is available at the end of the article
}

is the key strategy for preventing endangered populations from collapsing (Bascompte and Jordano 2007; Li et al. 2015a; Razafindratsima and Dunham 2015). The effective dispersal pattern is often estimated as the number of seed removal by frugivores (quantity) and the relative contribution of frugivores to seedling recruitment (quality) (Schupp 1993; Schupp et al. 2010). Operating under this view, most empirical studies have traditionally evaluated the role of dispersers in determining the effective dispersal patterns of plant species based on the above two aspects (Carlo et al. 2013; Rey and Alcántara 2014). However, the range of plant species always varies across different regions, causing variations in the effective disperser species and thus affecting the regeneration patterns of plant species at different sites. Therefore, information on effective dispersal may be important for implementing effective conservation strategies for plant species (Burns 2002, 2003). Given the inherent difficulty 
in studying effective dispersal patterns across plant distributional ranges, empirical evidence supporting the contribution of disperser species in endangered plant conservation remains limited.

In this study, we assessed the contributions of two functional groups of bird species (bulbuls and crows) in determining the effective dispersal patterns of Chinese yew (Taxus chinensis (Rehder and E.H. Wilson) Rehder) across three regions in eastern China. Specifically, we investigated: (1) the variation in the foraging behavior of bulbuls and crows on T. chinensis across regions, and how this variation impacts their seed removal, and (2) the variation in the perching behavior of bulbuls and crows across regions, and how this affects the birds' contribution to seedling recruitment.

\section{Methods}

\section{Species and study sites}

T. chinensis is a relic species that is endemic to China. This species is designated as "endangered" in the International Union for Conservation of Nature (IUCN) Red List (2013 version), and is ranked as a first priority protected species by the Chinese government (Tomas et al. 2013). The regeneration of the wild population of T. chinensis is not only limited by low pollination rates, seed-predator pressure, and low seedling survival rates, but also limited by different bird species (Li et al. 2015b).

For our study, we selected three field sites in eastern China (Shuangkeng village in Anhui, Chongtou village in Fujian, and Tongkeng village in Zhejiang) that had dense populations of $T$. chinensis. The Shuangkeng village $\left[30^{\circ} 00^{\prime} \mathrm{N}, 117^{\circ} 18^{\prime} \mathrm{E} ; 540 \mathrm{~m}\right.$ above sea level (a.s.l.)] is located in the southern part of Anhui Province, and contains 35 individual trees, which are distributed in a human-modified bamboo (Phyllostachys heterocycla) patch ( $\mathrm{Li}$ et al. 2015a). The Chongtou village $\left(25^{\circ} 15^{\prime}-\right.$ $25^{\circ} 35^{\prime} \mathrm{N}, 116^{\circ} 45^{\prime}-116^{\circ} 57^{\prime} \mathrm{E}$; $960 \mathrm{~m}$ a.s.l.) is situated in the Meihua Mountain National Nature Reserve in Fujian Province, and contains the largest wild population of $T$. chinensis (approximately 490 adults) in eastern China, including 200 trees that are over 500 years old (Li et al. $2015 \mathrm{~b})$. The Tongkeng village $\left(30^{\circ} 00^{\prime} \mathrm{N}, 119^{\circ} 22^{\prime} \mathrm{E}\right.$; $553-$ $638 \mathrm{~m}$ a.s.l.) contains the largest natural population of T. chinensis in Zhejiang Province (approximately 109 adults), including 34 trees that are more than 500 years old (Li et al. 2015a).

\section{Seed removal by bulbuls and crows across different regions}

For studying seed removal by bulbuls and crows across different regions, 10 aggregated mother trees were observed during two fruiting seasons (from late October to early December; Shuangkeng: 2010 and 2011;
Chongtou, Tongkeng: 2011 and 2012) at each site. Observations were made with binoculars from a hideout located at least $25 \mathrm{~m}$ away from the trees. Each mother tree was observed for an 8-h period once a day during the seasons, with observations being terminated when no more fruits remained on the mother trees.

For each bird that visited the mother tree, we recorded the species and the number of fruits swallowed during visits. If a group of conspecific birds visited the tree, we only focused on the most visible individual (Altmann 1974; Breitbach et al. 2010). After field study, we compared the visiting frequency and foraging amount per visit by each disperser species as a quantity pattern across different regions. Moreover, we used a machine-learning algorithm, random forest model, to plot how bird visiting frequency, foraging amount per visit, bird species, sites, and years influence the numbers of seeds that were removed (R package RandomForest) (Breiman 2001).

\section{Perching by dominated bulbuls and crows across different regions and its contribution to the seedling recruitment pattern}

We first used $10 \mathrm{~m} \times 10 \mathrm{~m}$ habitat cells to digitize the three study sites. Overall, we set 100 sampling cells in Shuangkeng, Chongtou, and Tongkeng, respectively. We then investigated the 1-year-old seedlings $(H \leq 10 \mathrm{~cm})$ in each cell of each site to determine the suitable recruitment habitat for T. chinensis.

For modeling the contributions of birds to seedling recruitment, we monitored the perching frequencies of two dominant species of bulbuls and crows during the fruiting period, from late October to early December (Breitbach et al. 2010; Li et al. 2015a, 2016). Bird perching was observed from high vantage points on the hills using binoculars. Birds were selected randomly and tracked in sessions that ended once visual contact was lost or if the focal bird could no longer be distinguished from the other conspecifics. During the sessions, the habitat used by birds and their position were recorded every $30 \mathrm{~s}$ (Breitbach et al. 2010; Spiegel and Nathan 2012).

We used the function to perform univariate Kriging models to interpolate seedling number and bird perching frequency in the sampled habitat plot. The method used for spatial interpolation is the krige function in the $\mathrm{R}$ package gstat. We tested the number of seedlings in the habitat cells by a generalized mixed-effect model, in which the perching frequencies of the bird species and sites were the covariates, while the survey year and their interaction term were the random effects. Because the numbers of seedlings were count data, the function glmer in the $\mathrm{R}$ package lme4 was used to run the generalized mixed-effect model with a Poisson link function. 


\section{Results}

\section{Seed removal by bulbuls and crows across different regions}

We performed $400 \mathrm{~h}$ of tree observations at each site. Five bulbul species and four crow species were recorded that dispersed the seeds of $T$. chinensis. The composition of disperser species and visiting frequency were similar at Shuangkeng and Tongkeng. However, these parameters at Chongtou differed, compared to the other two regions.
More bulbul and crow species with high visiting frequencies were recorded at Chongtou. The Red-billed Blue Magpie (Urocissa erythrorhyncha) was the most common disperser species of crow at all sites. However, the dominant bulbul species varied across the three sites. The Mountain Bulbul (Hypsipetes mcclellandii), Black Bulbul (H. leucocephalus), and Chestnut Bulbul (H. castanonotus) were the most common bulbuls at Shuangkeng, Chongtou, and Tongkeng, respectively (Table 1).

Table 1 Common bird dispersers visiting Taxus chinensis across different geographical regions

\begin{tabular}{|c|c|c|c|c|c|c|}
\hline \multirow[t]{2}{*}{ Bird species } & \multicolumn{3}{|c|}{ Number of visits per year } & \multicolumn{3}{|c|}{ Foraging amounts of fruits per visit (mean $\pm \mathrm{SE}$ ) } \\
\hline & Shuangkeng & Chongtou & Tongkeng & Shuangkeng & Chongtou & Tongkeng \\
\hline \multicolumn{7}{|l|}{ Crows } \\
\hline Urocissa erythrorhyncha & 23 & 15 & 28 & $5.4 \pm 1.8$ & $16.3 \pm 9.1$ & $6.4 \pm 1.9$ \\
\hline Copsychus saularis & & 21 & & & $8.0 \pm 3.5$ & \\
\hline Dendrocitta formosae & & 12 & & & $19.9 \pm 11.5$ & 2.0 \\
\hline Corvus macrorhynchos & & 1 & & & 10.0 & \\
\hline \multicolumn{7}{|l|}{ Bulbuls } \\
\hline Hypsipetes castanonotus & 22 & 13 & 49 & $4.6 \pm 1.4$ & $9.6 \pm 9.9$ & $3.0 \pm 0.9$ \\
\hline Hypsipetes mcclellandii & 75 & 2 & 12 & $4.2 \pm 1.2$ & $12.0 \pm 4.0$ & $3.3 \pm 0.8$ \\
\hline Hypsipetes leucocephalus & & 243 & & & $16.0 \pm 14.6$ & \\
\hline Pycnonotus jocosus & & 1 & & & $16.2 \pm 14.2$ & \\
\hline Spizixos semitorques & & 4 & & & $11.3 \pm 7.9$ & \\
\hline
\end{tabular}
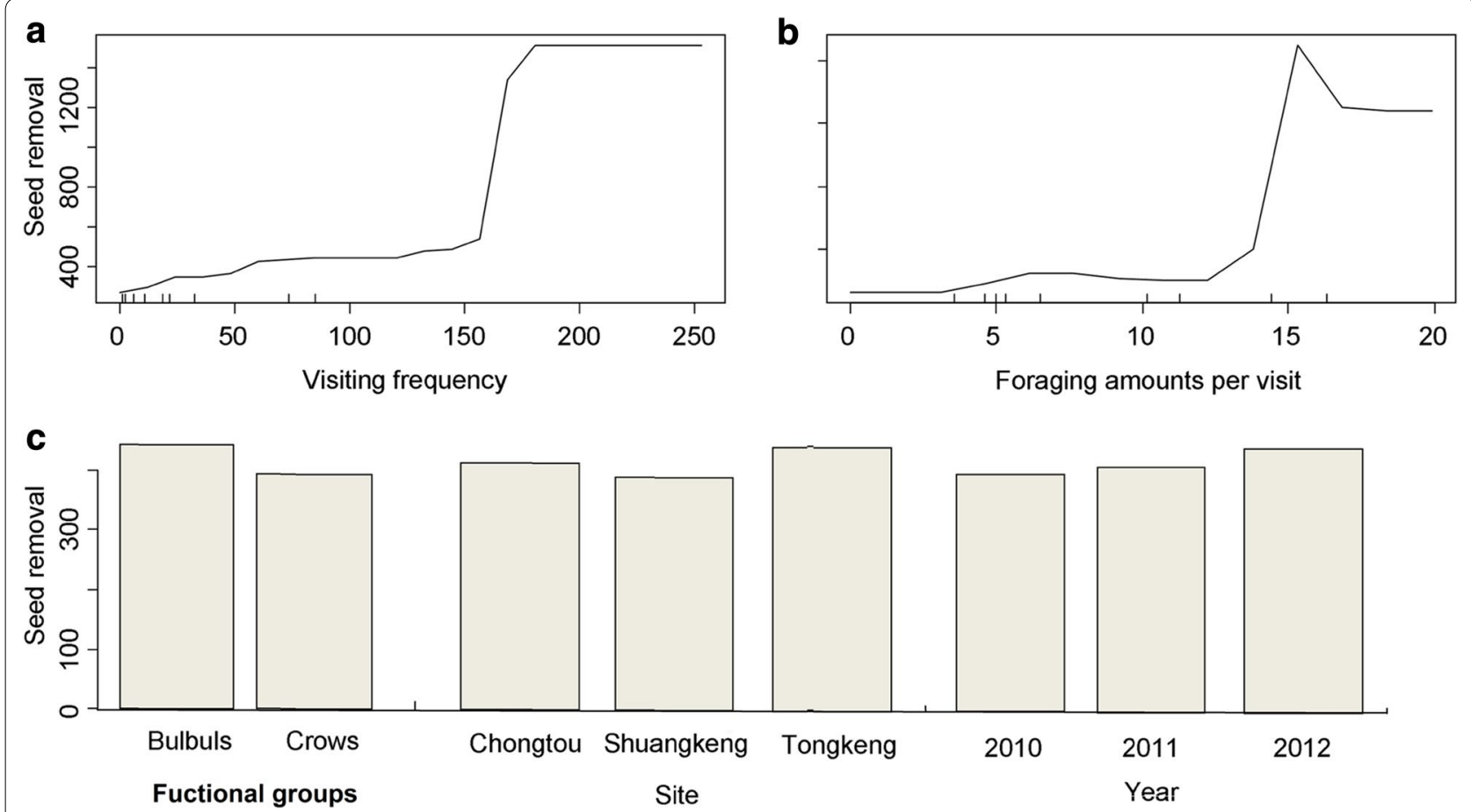

Fig. 1 A machine learning algorithm, random forest, for testing the association between seed removal and bird visiting frequency (a), foraging amounts per visit (b), bird functional type, site and years (c) across different geographical regions in eastern China 
The random forest results showed a positive association between the visiting frequencies of birds and seed removal across the three sites (Table 1). The birds contributed more to seed removal at Tongkeng in 2012 than at the other sites and years. Moreover, bulbuls contributed more to seed removal than crows across all the sites (Fig. 1).

\section{Effective seed dispersal patterns across different regions}

In the seedling census, we recorded 94, 693, and 245 seedlings at Shuangkeng, Chongtou, and Tongkeng, respectively. Although the distribution patterns of seedlings differed among the three sites, it was consistently affected by the post-foraging perching behaviors of bird dispersers (Fig. 2).

The generalized linear mixed-effects model (GLMM) showed that both bulbuls and crows significantly contributed to the number of seedlings (GLMM, bulbuls: $p<2 \mathrm{e}-16$; crows: $p<2 \mathrm{e}-16$ ) (Table 2 ) and the contribution of crows to seedling recruitment pattern was higher than that of bulbuls, which was consistent among the three sites (Fig. 3; Table 2).

\section{Discussion}

We have shown that different functional dispersers diverged in the aspects of seed removal and seedling recruitment pattern. While bulbuls removed more seeds than crows, crows improved seed dispersion probably by transporting the seeds to a safer site, an aspect of seedling recruitment pattern.

Bulbuls removed more seeds (Table 1; Fig. 1) thanks to certain characteristics of this group (food habits, flocked foraging, and population size). These characteristics place them in the birds- $T$. chinensis interactive system, as described by Li et al. (2015a, b), who found that the
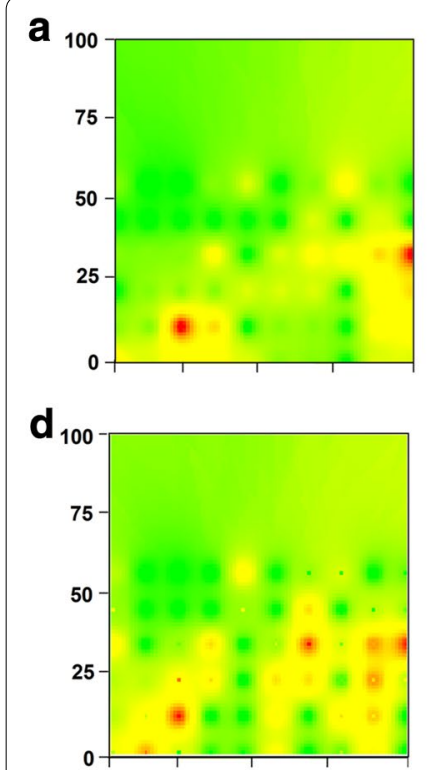

g

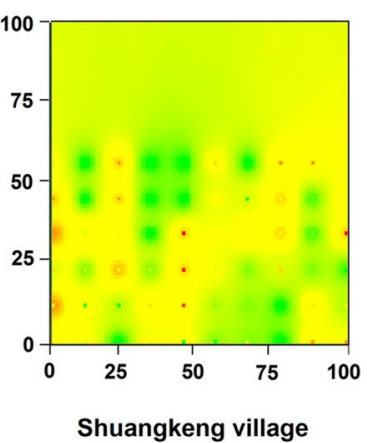

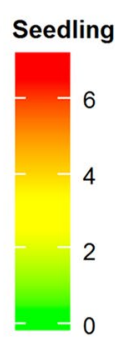

b
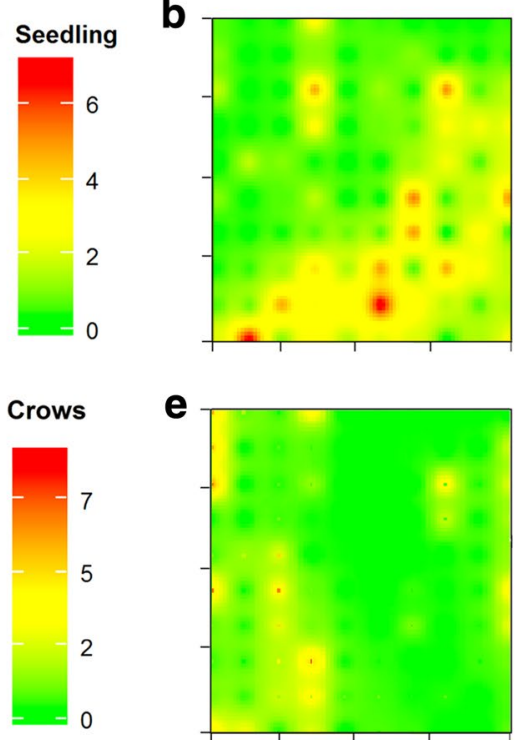

Bulbuls

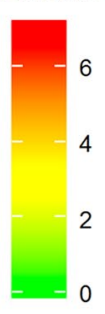

e

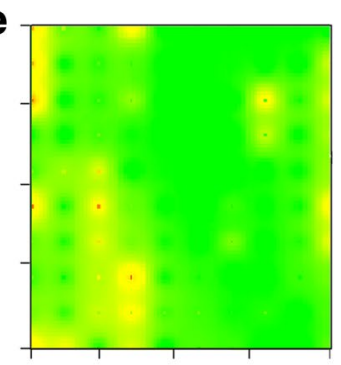

h

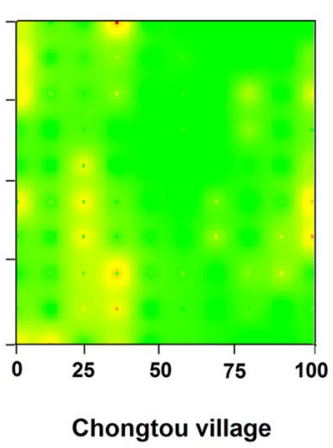

C

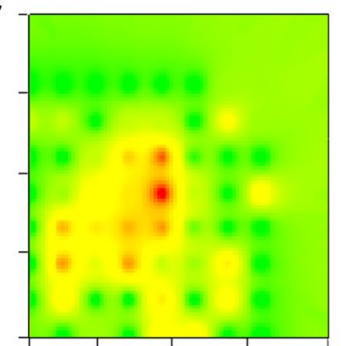

Seedling

Seedling
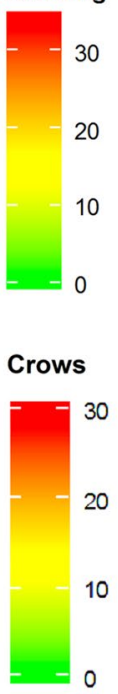

f

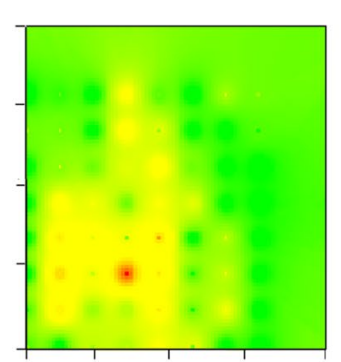

Crows

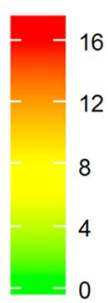

i

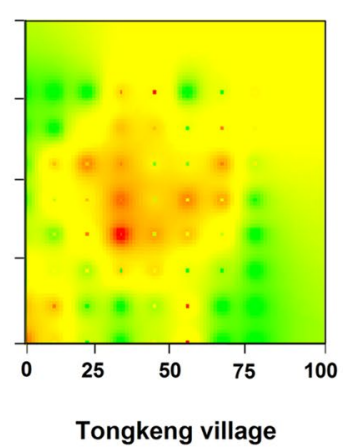

Bulbuls

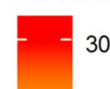

20

10

Tongkeng village

Fig. 2 Distribution of 1-year-old seedlings of Chinese yew (Taxus chinensis) (a-c) and perching frequency of bird dispersers (d-i) across different geographical regions in eastern China. a-c show the number of Taxus chinensis seedlings at Shuangkeng, Chongtou and Tongkeng respectively; $\mathbf{d}-$ f show 276, 512, 412 perching behaviors of the dominant crow (Urocissa erythrorhyncha) at Shuangkeng, Chongtou and Tongkeng respectively; $\mathbf{g - i}$ show 258, 878, 412 perching behaviors of the dominant bulbul (Hypsipetes mcclellandi) at Shuangkeng, Chongtou (H. leucocephalus) and Tongkeng (H. castanonotus) respectively; Coloured contours are interpolated from the values of the corresponding variables in the centroid of each habitat cell 
Table 2 A generalized linear mixed-effects model showing the association between number of seedlings and perching frequencies of the most common crows and bulbuls across different geographical regions

\begin{tabular}{lllll}
\hline Fixed effects & Estimate & SE & $\boldsymbol{Z}$ value & $\boldsymbol{p}$ value \\
\hline Factors & & & & \\
Intercept & 1.605 & 0.036 & 43.59 & $<2 \mathrm{e}-16^{* * *}$ \\
Crows & 0.042 & 0.004 & 10.95 & $<2 \mathrm{e}-16^{* * *}$ \\
Bulbuls & 0.051 & 0.004 & 11.37 & $<2 \mathrm{e}-16^{* * *}$ \\
Shuangkeng & -1.774 & 0.150 & -11.86 & $<2 \mathrm{e}-16^{* * *}$ \\
Tongkeng & -1.299 & 0.103 & -12.65 & $<2 \mathrm{e}-16^{* * *}$ \\
Crows: Bulbuls & -0.003 & 0.001 & -4.80 & $1.62 \mathrm{e}-06^{* * *}$ \\
Crows: Shuangkeng & 0.158 & 0.026 & 6.12 & $9.10 \mathrm{e}-10^{* * *}$ \\
Crows: Tongkeng & 0.132 & 0.011 & 12.34 & $<2 \mathrm{e}-16^{* * *}$ \\
Bulbuls: Shuangkeng & -0.033 & 0.037 & -0.90 & 0.3707 \\
Bulbuls: Tongkeng & 0.040 & 0.016 & 2.53 & 0.0113 \\
Random effects & Variance & SD & & \\
Groups & & & & \\
Year & 0 & 0 & & \\
\hline
\end{tabular}

Significance level: ${ }^{* * *} p \approx 0$; Dominant crow: Red-billed Blue Magpie (Urocissa erythrorhyncha); Dominant bulbuls: Mountain Bulbul (Hypsipetes mcclellandii) at Shuangkeng, Black Bulbul (Hypsipetes leucocephalus) at Chongtou and Chestnut Bulbul (H. castanonotus) at Tongkeng

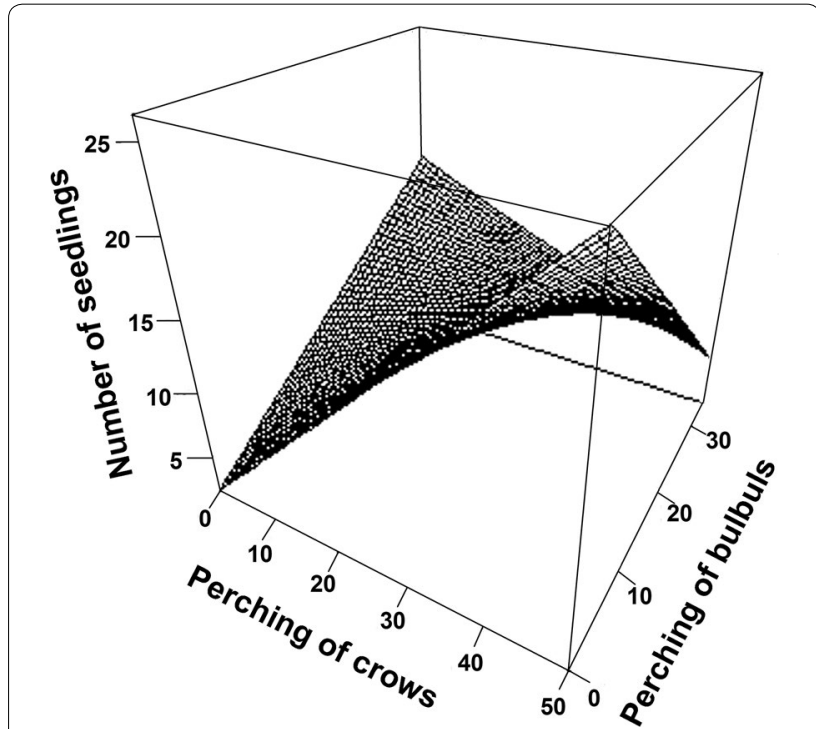

Fig. 3 A generalized linear mixed-effects model showing the interaction effects of bulbuls and crows to the number of seedlings across different geographical regions

obligate frugivores (bulbuls) consumed more seeds than the omnivores (crows). Moreover, the population size of bulbuls was larger than that of crows (Li et al. 2015a, b), leading to flocked foraging. This foraging strategy may result in the higher seed removal rates by bulbuls (McConkey and Brockelman 2011). This phenomenon has been detected in other studies on bird-dispersed Juniperus ashei and Prunus avium trees (Chavez-Ramirez and Slack 1994; Breitbach et al. 2010).

Our results also showed the importance of two functional groups of disperser species in relation to the seedling recruitment pattern of T. chinensis (Figs. 2, 3; Table 2). We found that bulbuls contribute less to the seedling recruitment pattern than crows. This difference may be explained by the differences in the habitat adaptation and body size of the birds, which, in turn, influence where the seeds are ultimately deposited (Jordano and Schupp 2000). For instance, the generalist crows have high tolerance to disturbance than the specialist bulbuls. Consequently, crows use a greater variety of sites than bulbuls (Babweteera and Brown 2009; Li et al. 2015b). This is important for the germination of yew seeds, especially in disturbed areas. Because the patches (e.g. bamboo patches) where the yew seeds could germinate were scattered over a large area, and were surrounded by the patches that were not suitable for the germination of the yew seeds (Li et al. 2015a) (e.g. carya or tea plantations), the post-foraging movement of the specialist bulbuls was limited; however, the post-foraging movement of the generalist crows was negligibly affected by the artificial landscape (Li et al. 2015b). Moreover, the larger crows may deposit $T$. chinensis further than the smaller bulbuls (MacKinnon et al. 2000), because body size is usually correlated with home range, bird movement, and gut passage time (e.g. Spiegel and Nathan 2007; Calviño-Cancela and Martín-Herrero 2009).

\section{Conclusions}

Our study highlighted the importance of studying the interaction between different functional disperser groups and endangered trees across different regions. Two functional groups of bird dispersers, bulbuls and crows, having complementary roles in seed removal and seedling recruitment, suggest the importance of considering these aspects in future plant conservation and management plans.

\section{Authors' contributions}

$\mathrm{BB}, \mathrm{NL}$, and $\mathrm{CL}$ designed the study. $\mathrm{BB}$ and $\mathrm{NL}$ performed data collection. $\mathrm{NL}$ and $\mathrm{XL}$ conducted all statistical analyses. All authors contributed to the writing and editing of the manuscript. All authors read and approved the final manuscript.

\section{Author details}

${ }^{1}$ Yunnan Forestry Technological College, Kunming 650224, China. ${ }^{2}$ College of Food Science, Nanjing Xiaozhuang University, Nanjing 211171, Jiangsu, China. ${ }^{3}$ Institute of Zoology, Chinese Academy of Sciences, Beijing 100101, China. ${ }^{4}$ Laboratory of Plant-Animal Interactions, College of Forest Resources and Environment, Nanjing Forestry University, Nanjing 210037, China. 


\section{Acknowledgements}

We thank Qiangjun Wang, Zhongwei Zheng, Dan Xu, Tianshi Xiong, and Yunfeng Yin for their contributions in the field. The study was supported by the Natural Science Foundation of China (Grant No. 31700468), the Natural Science Foundation of Jiangsu Province, China (Grant No. BK2017636), the Project of PhD Fund of Yunnan Forestry Technological College (Grant Number KY(BS)201404) and Yunnan province project Education Fund (Grant No. 2014Y568).

\section{Competing interests}

The authors declare that they have no competing interests.

\section{Ethics approval and consent to participate}

Not applicable.

Received: 2 October 2017 Accepted: 19 November 2017

Published online: 30 November 2017

\section{References}

Altmann J. Observational study of behavior: sampling methods. Behavior. 1974;69:227-63

Babweteera F, Brown N. Can remnant frugivore species effectively disperse tree seeds in secondary tropical rain forests? Biodivers Conserv. 2009:18:1611-27.

Bascompte J, Jordano P. Plant-animal mutualistic networks: the architecture of biodiversity. Ann Rev Ecol Evol Syst. 2007;38:567-93.

Breiman L. Random forests. Mach Learn. 2001;45:5-32.

Breitbach N, Laube I, Steffan-Dewenter I, Bohning-Gaese K. Bird diversity and seed dispersal along a human land-use gradient: high seed removal in structurally simple farmland. Oecologia. 2010;162:965-76.

Burns KC. Seed dispersal facilitation and geographic consistency in bird-fruit abundance patterns. Global Ecol Biogeogr. 2002;11:253-9.

Burns KC. Broad-scale reciprocity in an avian seed dispersal mutualism. Global Ecol Biogeogr. 2003;12:421-6.

Calviño-Cancela M, Martín-Herrero J. Effectiveness of a varied assemblage of seed dispersers of a fleshy-fruited plant. Ecology. 2009;90:3503-15.

Carlo TA, García D, Martínez D, Geditsch JM, Morales JM. Where do seeds go when they go far? Distance and directionality of avian seed dispersal in heterogeneous landscapes. Ecology. 2013;94:301-7.

Chavez-Ramirez F, Slack RD. Effects of avian foraging and post-foraging behavior on seed dispersal patterns of Ashe juniper. Oikos. 1994;71:40-6.

Howe HF, Smallwood J. Ecology of seed dispersal. Ann Rev Ecol Evol Syst. 1982;13:201-28.
Jordano P, Schupp EW. Determinants of seed disperser effectiveness: the quantity component and patterns of seed rain for Prunus mahaleb. Ecol Monogr. 2000;70:591-615.

Levine JM, Murrell DJ. The community-level consequences of seed dispersal patterns. Ann Rev Ecol Evol Syst. 2003;34:549-74.

Li N, Bai B, Wang Z, Luo F, Lu XZ, Lu CH. Avian seed dispersal and seedling distribution of the endangered tree species, Taxus chinensis, in patchy habitats. Plant Ecol Divers. 2015a;8:407-14.

Li N, Fang SB, Li XH, An SQ, Lu CH. Differential contribution of frugivorous birds to dispersal patterns of the endangered Chinese yew, Taxus chinensis. Sci Rep. 2015b. https://doi.org/10.1038/srep10045.

Li N, Li XH, An SQ, Lu CH. Impact of multiple bird partners on the seed dispersal effectiveness of China's relic trees. Sci Rep. 2016. https://doi. org/10.1038/srep17489.

MacKinnon JR, Phillipps K, He FQ. A field guide to the birds of China. New York: Oxford University Press; 2000.

McConkey KR, Brockelman WY. Nonredundancy in the dispersal network of a generalist tropical forest tree. Ecology. 2011;92:1492-502.

Nathan R, Muller-Landau HC. Spatial patterns of seed dispersal, their determinants and consequences for recruitment. Trends Ecol Evol. 2000;15:278-85.

Razafindratsima $\mathrm{OH}$, Dunham AE. Assessing the impacts of nonrandom seed dispersal by multiple frugivore partners on plant recruitment. Ecology. 2015;96:24-30.

Rey PJ, Alcántara JM. Effects of habitat alteration on the effectiveness of plantavian seed dispersal mutualisms: consequences for plant regeneration. Perspect Plant Ecol. 2014;16:21-31.

Schupp EW. Quantity, quality and the effectiveness of seed dispersal by animals. Vegetation. 1993:107(108):15-29.

Schupp EW, Jordano P, Gómez JM. Seed dispersal effectiveness revisited: a conceptual review. New Phytol. 2010;188:333-53.

Spiegel O, Nathan R. Incorporating dispersal distance into the disperser effectiveness framework: frugivorous birds provide complementary dispersal to plants in a patchy environment. Ecol Lett. 2007;10:718-28.

Spiegel O, Nathan R. Empirical evaluation of directed dispersal and densitydependent effects across successive recruitment phases. J Ecol. 2012;100:392-404.

Thomas P, Li N, Christian T. Taxus chinensis. IUCN red list of threatened species. Version 2013.1. www.iucnredlist.org. Accessed 15 November 2017.

Trakhtenbrot A, Nathan R, Perry G, Richardson DM. The importance of long-distance dispersal in biodiversity conservation. Divers Distrib. 2005:11:173-81.

\section{Submit your next manuscript to BioMed Central and we will help you at every step:}

- We accept pre-submission inquiries

- Our selector tool helps you to find the most relevant journal

- We provide round the clock customer support

- Convenient online submission

- Thorough peer review

- Inclusion in PubMed and all major indexing services

- Maximum visibility for your research

Submit your manuscript at www.biomedcentral com/submit
BioMed Central 